\title{
DIRECTIONS FOR IMPROVEMENT OF STATE FINANCIAL CONTROL IN UKRAINE
}

\author{
Nataliia MIEDVIEDKOVA ${ }^{1}$ \\ Taras Shevchenko National University of Kyiv, Ukraine
}

\begin{abstract}
The purpose of the paper is to offer the ways of development of the system of state financial control in Ukraine. The object of this research is the process of state financial control. Methodology. The research methods are systematic approach, groupings and tabular method, structural-functional method. In order to determine the types and elements of financial control it was used systematic approach. To characterize the distribution of financial control for the Lima Declaration; types end elements of state financial control; types of Supreme bodies of state financial control - groupings and tabular method. For disclosure the mechanism of the public financial control system the structural-functional method is used. Results of the survey shows, first of all, that recent steps of the government will improve the mechanism of control for the use of public fund. On the other hand, international experience includes the important features of the state financial control, which could be implemented in Ukraine. Furthermore, in Ukraine certain steps in standardization are taken to implement the international standards of control: first of all, Strategy modernization of the accounting system in the public sector in 2007-2015 was approved. Moreover, in 2013 in Ukraine the working meeting with the expert on the Twinning Fiche Projects took place, where the further direction of collaboration aimed at completion of development of the project documentation was presented. Nevertheless a lot of questions of the state financial control system standardization remain open. Unsystematized standards have negatively affects on their usage, results in an ambiguous interpretation of separate situations which arise during control activity. Practical implications. The first thing that needs to be said is that types of state financial control according to the allocation of authorities between the different bodies were considered. Another important thing is that directions for improvement of state financial control in Ukraine were suggested. In addition to previous practical implications, the important role of standardization in improving of state financial control in Ukraine was highlighted, because it has a lot of positive effects on a state financial control: it helps to achieve common aims of transparency and reporting; to plan and conduct audits, and their usage provides for the professionalism and high quality of control results. Value/originality. Longitudinal analyze of foreign experience helped to provide directions for improvement of state financial control in Ukraine. The main areas which should be focused on are: providing by Accounting Chamber of Ukraine to represent the State in legal proceedings; introducing a mechanism to hold officials' responsible for violations of financial discipline. Besides it, standardization is the way in improving of state financial control, because nowadays a correct interpretation of indicators such as state debt and state deficit are important in terms of assistance from international organizations.
\end{abstract}

Key words: control, state financial control, preventive control, Supreme bodies of state financial control, standardization

JEL Classification: G38, H83

\section{Introduction}

An important part of management system that guarantees quality and ensure an effective implementation of governmental activity is control. Control as a type of relationship is the attitude of the subject to their own activities or the activities of other subjects in terms of compliance with certain rules. Control may be state and public and be used in various structures, including nongovernmental ones.
State control is one of the functions of the government of assessing the legality of the object of control and performed by relevant state authorities. Therefore the most relevant definition of control is "a function of the state and society, their institutions and structures to the use of different evaluation and supervision mechanisms for the activities of structures, institutions and organizations, and compliance with laws and other rules that may be established by the state".

\footnotetext{
Corresponding author:

${ }^{1}$ Department of Finance, Taras Shevchenko National University of Kyiv, Ukraine.

E-mail: nsmedvedkova@mail.ru
} 
There are different types of state control: presidential control, parliamentary control, control of the executive authorities, judicial control. But a special place in the system of the state control belongs to the state financial control. State financial control is an instrument of implementation of financial policies, ensures the formation and effective use of financial resources of the state for achieving its objectives in the field of finance. Therefore, the purpose of financial control, followed from this definition, is to identify deviations from the adopted laws, standards, effectiveness, resource management.

There are 3 main forms of financial control: preventive control, operational control, retrospective control. Operational control is performed during the financial and economic operations, retrospective control - respectively after the reporting period. But the most important one is preventive control which is performed until financial transactions. The assessment of validity of programs and financial forecasts, financial plans based on the analysis of macroeconomic indicators of the state economy are carried out. It is performed to prevent the violation of laws, rational use of financial resources.

Unfortunately, the Accounting Chamber doesn't perform a preventive function of financial control that does not contribute to the development control process in Ukraine and increase its effectiveness.

According to the budget transparency rating, which was conducted by worldwide network of International Budget Partnership, Ukraine ranked 56 out of 102 countries. Compared with previous years, Ukraine has been as high as 46 out of 100 . It determines the need for improving the state control of budgetary funds.

Over the last 14 years the following acts have been adopted, such as a Concept for the development of public internal financial control until 2017, Guidelines for the organization of internal control by managers of government money in its institutions and in subordinate budget institutions, Internal Audit Code of Ethics, etc (Tkachenko, 2015).

Among recent steps of the government are the following. First one is the positive changes made to the Law $\ll$ On public procurement» (State Financial Inspection of Ukraine was given a transfer function of monitoring with the ability to restrict of State Treasury Service of Ukraine's verification powers. In addition, the Ministry of Economic Development and Trade of Ukraine intends by the end of 2016 to transfer all government procurement in electronic format.

Second, EU experts in Ukraine started a monitoring mission to combat money laundering and terrorist financing.

Third, The Ministry of Finance of Ukraine presented the official portal which places the information on transactions in the Treasury Single Account in the public domain. From 01.01.2016 the transaction not only of the state treasury will be available, but also all the data of the state budget, including utilities and more.
The above measures will improve the mechanism of control for the use of public funds; create its integrity and fairness. It will make more transparent use of public funds. However, international experience includes the important features of the state financial control, which could be implemented in Ukraine.

\section{Types of state financial control}

Discussions on state financial control in Ukraine are often reduced to the allocation of powers between the different bodies: State Financial Inspection of Ukraine, Accounting Chamber of Ukraine, State Fiscal Service, Ministry of Finance of Ukraine, State Treasury of Ukraine, control and revision units of ministries and departments.

Internal financial control (control of management) is performed by a State Financial Inspection and Inspection services of central executive bodies which are subordinated to the government. But world practice shows, external financial control considers bodies which are not subject to government and accountable to Parliament and the public (they are called Supreme bodies of state financial control) (Figure 1).

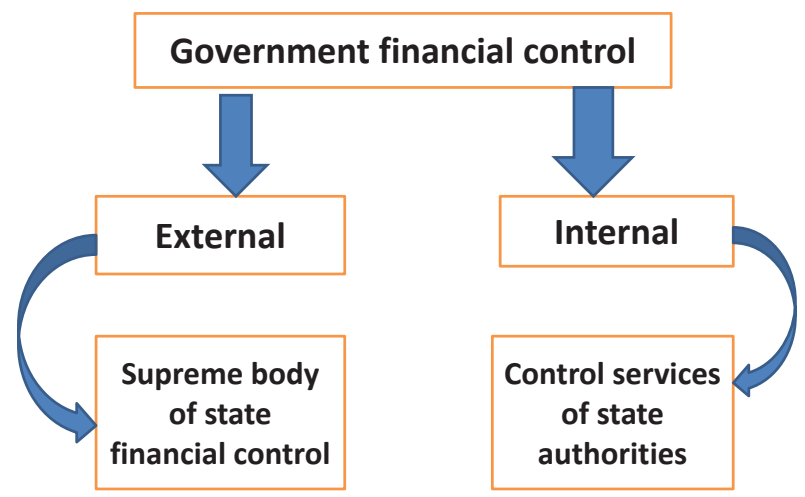

Fig. 1. Distribution of financial control for the Lima Declaration

Besides the allocation between internal and external financial control, one of the major steps towards European system of public financial control is the development and entry into force of the new Budget Code of Ukraine and especially the new wording of Article 26 according to it: compulsory introduction should take place for the basic components of the European model of PIFC - internal control and internal audit.

The basic principle of public internal financial control is the separation of internal control and audit.

Internal financial control is a management instrument that enables the management of state and municipal sectors and checks the status of the relevant tasks to carry out a series of measures to improve the efficiency of institution's activity. The head of management team of state and municipal sectors is responsible for the establishment and functioning of internal control.

Internal audit has to define how the implemented internal control is performed. The purpose of internal 
audit is to provide independent advice and consultation aimed to improve the work of state and municipal sectors, improving management processes. Internal audit can be performed centrally - state financial inspection and decentralized - authorized independent units, subordinated directly to heads of public or municipal institutions (Dikan, Synyuhina, Deyneko, 2014).

World practice shows that the Supreme bodies of state financial control play an important role in the control of state financial resources contribute to the effective management of public finances at all (Homutenko, Homutenko, 2011). The classification of Supreme bodies of state financial control is based on the independence of authorities and their powers (Figure 2).

The Accounting Chamber of Ukraine is the Supreme Audit Institution of Ukraine operating since 1996. It acts according to the Law "On the Accounting Chamber", the Budgetary Code of Ukraine and other by-laws. It acts as a constitutional body of the Government's external financial control mechanism, and as independent authority acting on behalf of Parliament of Ukraine. It executes control and supervision over revenues and expenditures of the State Budget.

The activities of Accounting Chamber of Ukraine are audits, provision of expert analyses, monitoring and evaluation. The Accounting Chamber of Ukraine has been performing financial, performance and compliance audits of the entities, institutions, organizations and Ministries which utilize State Budget funds.

The Accounting Chamber of Ukraine develops cooperation with Supreme Audit Institutions and international organizations, concludes agreements on cooperation with them, such as Mexico Declaration on SAI Independence (2007), the Lima Declaration of Guidelines on Auditing (1977).

Accounting Chamber of Ukraine is a membership of International Organization of Supreme Audit Institutions (INTOSAI) since 1998, European Organization of Supreme Audit Institutions (EUROSAI) since 1999.

Terms of state financial control are identified by the Lima Declaration of Guidelines on Auditing (adopted in 1977 at the Congress of the International Organization of Supreme Audit Institutions (INTOSAI)). INTOSAI is one of the most important organizations in the world in the area of state control, which includes supervisory bodies of 130 countries.

Currently EUROSAI brings together 48 of Supreme Audit Institutions (SAIs of 47
European and European Court of Auditors). According to Article 1 of the Charter EUROSAI, the main purpose of the organization - to promote cooperation between the national SAIs which are part of it as well as the exchange of information and documentation, research on control of public finances, the creation of university departments of public audit and unification of terminology in the area of financial control.

The main priorities of International Cooperation are maintaining bilateral and multilateral cooperation with foreign Supreme Audit Institution, external auditing, institutional capacity building, and participation in activities of international organization.

Priorities of the Accounting Chamber's Bilateral Cooperation are exchange of experience and best practices on methodologies and audit procedures, development of cooperation under the terms of Agreements on Cooperation and implementation of join Action Plans, development of mutually beneficial relations with foreign SAIs, carrying out international parallel or coordinated audits.

There are several approaches to the types of Supreme bodies of state financial control. Anyway, these classifications are based on the independence of such bodies and their authority (Homutenko, Homutenko, 2011). Accounting Chamber of Ukraine is not entrusted with judicial powers (Figure 3).

According to the new Law of Ukraine «On the Accounting Chamber» (2015) the Accounting Chamber of Ukraine is now free from any influence. The Chamber is determined as organizationally, functionally and financially independent institution. And on behalf of Parliament it monitors not only the usage of the state budget, but also the flow of funds.

Also, the law states that interference by public authorities, local governments, political parties and public

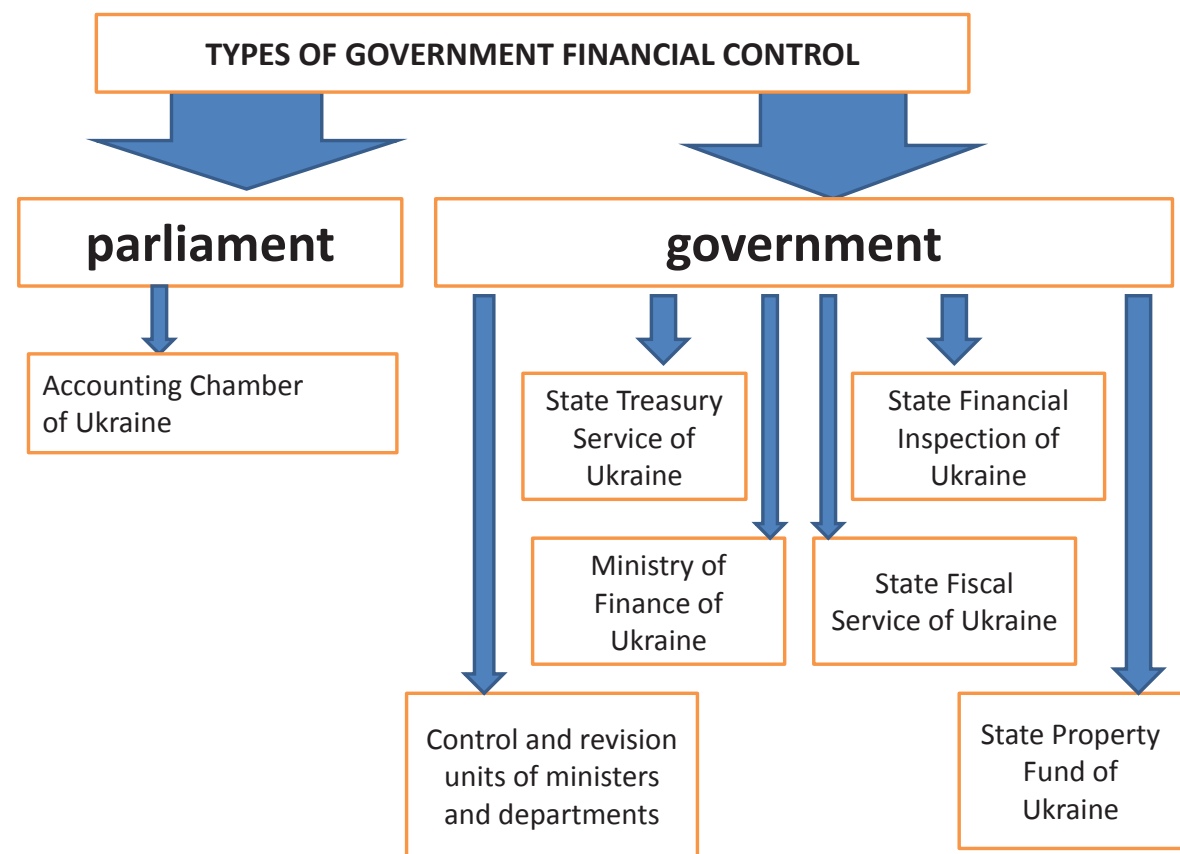

Fig. 2. Types end elements of state financial control 


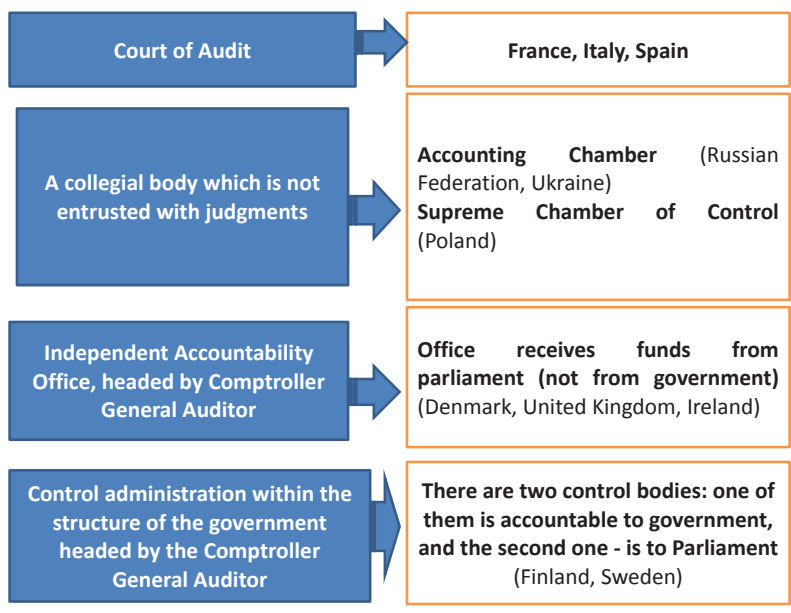

Fig. 3. Approaches to the types of Supreme bodies of state financial control

associations, enterprises, institutions and organizations in the Accounting Chamber is prohibited.

The Chamber on behalf of Parliament carries out external state financial control of the use of funds from the state budget performance, audit, examination, analysis and other control measures. It has to submit a quarterly report to Parliament on the results of audits and conclusions on the implementation of the law on the state budget and proposals to eliminate deviations and violations.

\section{Directions for improvement of state financial control in Ukraine}

The main areas which should be focused on are: providing Accounting Chamber of Ukraine to represent the State in legal proceedings; introducing a mechanism to hold officials' responsible for violations of financial discipline.

Providing Accounting Chamber of Ukraine to represent the State in legal proceedings. In Ukraine, Account Chamber performs the State Financial Control function in the part of monitoring of using of the State Budget of Ukraine and Government financial inspection of Ukraine within its powers defined by law.

However, the Accounting Chamber of Ukraine does not fulfil the preventive functions, but only captures and records violations of budget legislation and inform the police about the committed violations.

World experience shows that if the external control body does not perform judicial functions (USA, Italy, Czech Republic), the effectiveness of control goes down because of the additional links in the chain - a law enforcement agency. In this case the compensation does not exceed $20 \%$ of the total disclosed violations. The positive effect is empowering audit of the quasi-judicial functions (France, Hungary).

Introducing a mechanism to hold officials' responsible for violations of financial discipline. The important sign of readiness to join the EU is to establish procedures for compensation for loss of finance. But today Ukrainian legislation does not provide an effective mechanism for compensation of lost budget funds and the responsibility of officials for violations of financial discipline.

Experience in other countries shows that to deal with cases of abuse by tax officials of their rights there is a widespread practice of recovery of costs and expenses from the tax authority. Poland has a disciplinary and financial liability of officials, and if the taxpayer in court proves that he is right, the tax authority returns the amount which was paid plus $13 \%$.

\section{Standardization as the way in improving of state financial control}

The underestimation of systemic approach to the development of domestic standards of financial control maximally takes into account the features of the domestic system of state finances, influences its effectiveness and results in unproductive financial and labour charges.

Standardization is important element for ensuring fiscal transparency and finance information reliability in Ukraine. It has a lot of positive effects on a state financial control. Firstly it helps to achieve common aims of transparency and reporting. Secondly it helps to plan and conduct audits, and their usage provides for the professionalism and high quality of control results, sequence in presenting these results to society. Thirdly, standards not only set the correct procedure of state financial control and audit, but also strengthen these functions in the system of democratic institutes of state administration (Liubenko, 2015).

The results of state financial control and audit must be based on the application of common procedures and methods, and also on sufficient evidences which enable a state inspector or a public accountant to express logical and competent opinions in the report.

In Ukraine certain steps in standardization are taken to implement the international standards of control. The main direction of accounting reform in the public sector defined by the Cabinet of Ministers of Ukraine of 16 January 2007 №34 on Approval Strategy modernization of the accounting system in the public sector in 20072015, which reflects objectives, goals, main directions and measures of reform.

On December 18, 2013 in the premises of the EU Delegation in Ukraine the working meeting with the expert on the Twinning Fiche Projects preparation "Improvement of the State Internal Financial Accounting in Ukraine” and "Transposing of the International Public Sector Accounting Standards (IPSAS) into the System of Public Audit of Ukraine" took place. During the event the Twinning Fiche Projects were presented as well as the issue on cooperation within the framework of the projects were presented, further direction of collaboration aimed at completion of development of the project documentation was approved.

However, a lot of questions of the state financial control system standardization remain open. Unsystematized standards have negatively affects on their usage, results 
in an ambiguous interpretation of separate situations which arise during control activity. Nowadays a correct interpretation of such indicators such as state debt and state deficit are important in terms of assistance from international organizations.

\section{Conclusion}

The analysis shows the need to improve a state financial control. A lot of problems should be solved including judicial issues and issues of standardization. The most important judicial issue is to provide Accounting Chamber of Ukraine to represent the State in legal proceedings and to fulfil the preventive functions. In the developed countries financial control is a part of the state regulation in order to detect deviations from the regulations and violations of the principles of legality and efficiency.

The standards help to get a common language and common approaches and avoid differences in interpretation of financial statements. It's important for internal use within an institution, and also for external users. Standards not only improve budget transparency rating but also promote trust by international financial organizations. It's especially necessary for Ukraine, considering the need of external funding to implement structural reforms.

\section{References}

Strategy of modernization of the accounting system in the public sector in 2007-2015 (Cabinet of Ministers of Ukraine; 16.01.2007 № 34)

On the Accounting Chamber (Verkhovna Rada of Ukraine; Law of 02.07.2015 № 576-VIII)

On public procurement (Verkhovna Rada of Ukraine; Law of 10.04.2014 № 1197-VII)

Concept for the development of public internal financial control until 2017 (Cabinet of Ministers of Ukraine; 24.05.2005 №158)

Guidelines for the organization of internal control by managers of government money in its institutions and in subordinate budget institutions (Ministry of Finance of Ukraine; 14.09.2012 № 995)

ISSAI 300 Performance Audit. (2012). Retrieved from: http://www.issai.org/media/69911/issai- 300-english. pdf. 60

ISSAI Executive Summaries. (2013). Retrieved from: http://www.intosai.org/issai-executive-summaries.html

Lima Declaration. (2012). Available at: http://www.issai.org/media/12901/issai_1_e.pdf

Lyubenko, A. (2015). Standartization of state financial control on the basis of system approach. Ekonomika / Economics, №94(1): 52-60

Dikan, L.V., Synyuhina, N.V., Deyneko, Y.V. (2014). Internal control under public financial control system reformation: the state of implementation and development prospects. Actual problems of economics, Vol. 4(154): 446-454

Tkachenko, O. (2015). European vector in the development of the system of state financial control. Finance control, Vol. 2(109): 42-47

Homutenko, V.P, Homutenko, A.V. (2011). Accounting Chamber as a body of parliamentary financial control Ukraine. Socio-Economic Research Bulletin, Vol. 2(42): 466-471

\section{Наталия МЕДВЕДКОВА}

\section{НАПРАВЛЕНИЯ СОВЕРШЕНСТВОВАНИЯ ГОСУДАРСТВЕННОГО ФИНАНСОВОГО КОНТРОЛЯ В УКРАИНЕ}

Аннотация. Целью данной работы является предложение направлений развития системы государственного финансового контроля в Украине. Объектом данного исследования является процесс осуществления государственного финансового контроля. Методология. Методами исследования являются системный подход, группировка, табличный метод, структурно-функциональный метод. С целью определения типов и элементов финансового контроля использован системный подход. Для характеристики распределения государственного финансового контроля согласно Лимскойдекларации; видов иэлементов государственного финансового контроля; типов Высшихорганов финансового контроля-метод группировки и табличный метод. Для раскрытия механизма осуществления системы государственного финансового контроля - структурнофункциональный метод. Результаты исследования показали, что в последнее время правительством сделаны шаги для улучшения механизма контроля за использованием государственных средств. С другой стороны, международный опыт включает в себя важные аспекты государственного финансового контроля, которые могут быть реализованы в Украине. Кроме того, в Украине реализованы определенные шаги по внедрению международных стандартов контроля: в первую очередь, утверждена Стратегия модернизации системы бухгалтерского учета в государственном секторе в 2007-2015 годах. Кроме того, в 2013 году в Украине состоялась рабочая встреча с экспертом Twinning Fiche Projects, где были утверждены дальнейшие 
направления сотрудничества, направленного на завершение разработки проектной документации. Тем не менее, много вопросов стандартизации системы государственного финансового контроля остаются открытыми. Отсутствие систематизации стандартов негативно сказывается на их использовании, приводит к неоднозначной интерпретации отдельных ситуаций, которые возникают в ходе осуществления контрольной деятельности. Практическое значение. Во-первых, были рассмотрены виды государственного финансового контроля в соответствии с распределением полномочий между различными органами. Во-вторых, предложены направления совершенствования государственного финансового контроля в Украине. В дополнение к предыдущим практическим значениям была отмечена важная роль стандартизации в улучшении государственного финансового контроля в Украине, поскольку она оказывает положительные эффекты на осуществление государственного финансового контроля, а именно: способствует достижению общих целей прозрачности и отчетности; позволяет планировать и проводить проверки, а их использование обеспечивает профессионализм и высокое качество результатов контроля. Значение/оригинальность. Полученный анализ зарубежного опыта помог разработать направления совершенствования государственного финансового контроля в Украине. Основные направления должны быть сфокусированы на предоставлении Счетной палате Украины права представлять государство в судопроизводстве; введение механизма ответственности должностных лиц за нарушения финансовой дисциплины. Помимо этого, стандартизация является направлением улучшения государственного финансового контроля, поскольку в настоящее время корректная интерпретация таких показателей как государственный долг и дефицит государственного бюджета имеют важное значение с точки зрения получения финансовой помощи со стороны международных организаций. 